\title{
OPPORTUNITIES TO LEARN HISTORY AND CULTUROLOGY AND TO DEVELOP DIGITAL COMPETENCE IN THE AGE OF INFORMATION TECHNOLOGY
}

\author{
Pāvels Jurs ${ }^{1}$, Dina Bethere ${ }^{2}$ \\ ${ }^{1,2}$ Liepaja University, Latvia
}

\begin{abstract}
Technological progress, which sets scenarios for the development of humanity, affects the pattern of human behaviour in the most direct way and becomes an integral part of life, serving as progressives and at the same time also as regressive means in the educational process. The school should follow the modern digital age so it is necessary to offer students to learn the content of learning in an interactive, understandable, achievable and educational way. In order to facilitate the interaction of the digital competence of student's with knowledgebuilding in the learning process of History and Culturology, two years of development resulted in the creation of a website enabling students to learn more successfully history and culturology. It should also be noted that the European Commission highlights the digital competence as one of the key competences for lifelong learning: it is recommended that the European Union should raise and improve the level of digital competences at all stages of education and training (European Commission, 2018). The aim of this article is, highlighting the importance of digital competence and information technology in the education process, identify students' growth rates in History and Culturology studies using the learning platform developed and tested www.pavelsjurs.lv. The article reflects the introduction of innovation in the History and Culturology subjects through an open interactive learning platform that can be used in daily education at school and for online learning.

Keywords: culturology, digital competence, educational process, history, information technology, students.
\end{abstract}

To cite this article:

Jurs, P. \& Bethere, D. (2020). Opportunities to Learn History and Culturology and to Develop Digital Competence in the Age of Information Technology. Education. Innovation. Diversity, 1(1), 27-36.

DOI: http://dx.doi.org/10.17770/eid2020.1.4421

\section{Introduction}

With the entry of digital technologies, the learning process is becoming more versatile and diverse, adapting to societal and labour market requirements, educational content conditions and the preconditions for the cognitive and metacognitive development of students'. Digital technologies are today the engine of innovation, contributing to the growth of the global economy (Kluzer \& Rissola, 2015). In parallel, the importance of access to education and the digital competence of students in the learning process through digital technologies should be emphasised. Thus the digitization and accessibility of the curriculum is gaining importance. If a student has access to an intelligent and standard-appropriate digital educational content, the learning process is to some extent facilitated by the student - different smart devices can be used at all times and places, educational content becomes more accessible, providing opportunities for self-learning and better preparation, such as upcoming exams, and new opportunities for learning through distance learning.

In addition to accessing and learning content in an interactive way through information technologies, the digital skills of students' are one of the key issues. In order to be able to adapt to a rapidly changing world, it is necessary, through a multi-plurality of education, to promote a set of basic human skills, including digital competence, which will help to adapt to the changes in globalisation (Vuorikari, Punie, Carretero \& Brande, 2016). As confirmed by Eurostat available statistics in the context of digital skills, in 2015, nearly half $(44,5 \%)$ insufficient digital skills have been identified among EU citizens aged 16-74 in order to be able to participate fully in socio-economic processes (Eurostat data, 2015). Meanwhile, in a report 
published by the European Commission (2017) "Europe's Digital Progress Report 2017" it is concluded that: (I) 79\% of EU citizens use the Internet at least once a week; (II); $71 \%$ of EU citizens use the Internet every day; (III) $44 \%$ of EU citizens do not have sufficient digital skills; (IV) $14 \%$ of EU citizens do not have digital skills and do not use the Internet; (V) $37 \%$ of job seekers have insufficient digital skills; (VI) $11 \%$ of job seekers do not have digital skills at all (European Commission, 2017).

It should be noted that school achievements on History subject at the end of grade 12 are relatively low in the centralised exam of History, which is organised on a voluntary basis by students in general education institutions. In analysing the report published by the National Centre for Education of the Republic of Latvia in 2019 on the results of the State examination work, it should be concluded that the average History centralised examination rate in Latvia is only 40.93\% between 2017 and 2019, while the historical minimum exam rates at the end of grade 9 are $61.11 \%$ (Valsts Izglìtības satura centrs, 2019).

The methods used in the article are: theoretical (scientific and methodical literature, analysis of regulatory enactments) and empirical (data extraction, processing and analysis). The article highlights the analysis of the concept of digital competence, describing the development of learning platforms to study History, Culturology. There was also a student survey conducted to assess the impact of the effectiveness of information technology on the learning process and students learning outcomes. The theoretical and empirical research carried out led to the achievement of the aim of the article: highlighting the importance of digital competence and information technology in the education process, identify students' competence growth rates in History and Culturology through the development and testing of an interactive learning platform www.pavelsjurs.lv.

\section{Topicality and necessity of digital competence in the pedagogical process}

In the era of information technology, promoting the digital competence of students' in the pedagogical process is becoming one of the most important elements of learning. Both: the importance and necessity of digital competence are also highlighted in policy planning documents at national level, for example, report of the Ministry of Education and Science of the Republic of Latvia "Digital competence in the educational process" it is emphasized that: "digital competence is the ability to use technology to acquire, store, create, evaluate, and exchange information to securely communicate and collaborate on collaborative / social networks using the Internet and technology capabilities; ability to use information technology with conviction and criticism in education, work and leisure." (Latvijas Republikas Izglītības un zinātnes ministrija, 2015).

The concept of digital competence as noted by the European Commission in its report "Key Competences for Lifelong Learning - A European Framework", involves the convincing and critical use of information society technologies for work, leisure and everyday communication. They are based on computer skills for obtaining, evaluating, storing, creating, presenting, exchanging information, communicating and networking over the Internet. Digital competence requires a clear understanding and knowledge of the nature of information society technologies, their meaning and potential in everyday life. Necessary digital skills include the ability to search, collect and process to use information, critically and systematically assessing the meaning of information, and understanding the differences between real and virtual information (European Commission, 2017, p.7). Critical thinking and practical knowledge are very important elements of digital competence, as the researcher Z. Rubene emphasizes: "education, upbringing based on the notion that by mechanically taking over non-reflective knowledge, developing the mind, can become a prototype of the mass society. Thinking, inventing, solving important problems is possible only in individual, creative intellectual activity. If the learning 
process does not exercise reasoning; does not encourage human initiative, but merely acquires non-practical knowledge, education becomes a mean of building a mass of indifferent, neutral individuals." (Rubene, 2004, p. 27-28).

It should be noted that the use of information technologies to promote digital competence requires critical and informed treatment of students with available information arising from the self-directed learning process and the responsible use of interactive media. These processes, which can conditionally be called as the preparation phase of digital competence, should be directed initially through the professional and purposeful mediation of the teacher. Thus, in the light of promoting digital competence in the pedagogical process, it would be advisable to promote the development of the digital competence of young people, not only, for example, in Informatics lessons, but in any other subject, by ensuring effective learning of the learning process through the digital platform.

Digital competence can be characterised by a number of components that reveal the digital competence framework. For example, as elements of the digital competence structure can serve:

- informative and media component - knowledge, skills, motivation and responsibility for information search, selection and analysis;

- communicative component - knowledge, skills, motivation and responsibility for different forms of communication;

- the technical component - knowledge, skills, motivation and responsibility for the effective and safe use of technical equipment;

- consumer component - knowledge, skills, motivation and responsibility in solving various problem situations using information technology in everyday life (Soldatova, Nestik, Rasskazova \& Zotova, 2013, p. 141).

On the other hand, from the European Commission's perspectives, the digital competence framework is described as:

- information and data literacy - browsing, searching and filtering data, information and digital content, evaluating data, information and digital content, managing data, information and digital content;

- communication and collaboration - interacting through digital technologies, sharing through digital technologies, engaging in citizenship through digital technologies, collaborating through digital technologies, netiquette, managing digital identity;

- digital content creation - developing digital content, integrating and re-elaborating digital content, copyright and licences, programming;

- safety - protecting devices, protecting personal data and privacy, protecting health and well-being, protecting the environment;

- problem solving - solving technical problems, identifying needs and technological responses, creatively using digital technologies, identifying digital competence gaps (European Commission, 2007, p. 8-9).

Digital competence involves the confident and critical use of Information Society Technology for work, leisure and communication: promoting digital competence is today an integral part of educational content. Being aware of the rapid development of information technologies and the need to promote students' digital competence in educational establishments, including Latvia, the new competence-based basic education content, which was approved at the end of 2018, defines digital competence as one of the key competences in order to use digital technologies responsibly and effectively, acquire knowledge, create new content, share content and communicate, critically and constructively assess the role of technology and media society (Ministru Kabineta noteikumi Nr. 747, 2018).

By bringing together the various approaches described above in the content of the concept of digital competence, recognising the need to promote digital competence in the learning 
process, it can be concluded that digital competence is: (I) students' knowledge and skills, by carefully analysing and critically evaluating, obtaining and processing information; (II) safe and dignified virtual cooperation between students' using different forms of communication; (III) knowledge, skills and dignity of students' in the development, storage and distribution of digital content; (IV) students' knowledge, skills and responsibility for security and problemsolving aspects in the digital environment.

\section{Digitalisation of learning content in History and Culturology classes}

In order to promote the development of a student as a personality, it is necessary constantly think about improvements in teaching and learning, taking into account both the rapid development of information technology and the demands of the labour market in relation to the cognitive and metacognitive preconditions of students. The teacher should provide an active and intellectually stimulating learning process in a responsive environment, where student receives the necessary support (Fišers, 2005, p. 200). As a result, the teaching and learning process becomes a multi-faceted, focused and systematic collaboration between a student and teacher, where, with the professional skills and support of teacher, a student learns the skills needed for life, gains up-to-date knowledge and creates a positive and dignified attitude. Measuring and harmonising the activities of the teacher and the student in achieving didactically justified development is the most important condition of teaching as a condition of fact (Žogla, 2001, p. 174). It is the teaching method chosen by the teacher that largely determines the course of development of students' competence development. Teaching method is a system of teacher-student didactic co-operation to develop pupils' knowledge and skills and develop cognitive abilities (Zelmenis, 2000, p. 111). Training methods for learning any subject must also be undermined by age requirements and technology benefits: neither school nor teacher can ignore technological progress, methodically justified approaches must be found where the benefits of modern technologies provide added value in improving the learning process and promoting the quality of education. A teacher needs to focus on a broad range of innovation technologies in day-to-day work in order to promote evolving learning and the effectiveness of learning history, both from the perspective of students and from the perspective of the teacher themselves. Meanwhile, the thoughtful use of information technology in the pedagogical process can enhance students' curiosity, self-study and relative freedom of action (Nikulina, 2000).

The acquisition of a historical curriculum in general education institutions in Latvia is governed by the Cabinet Regulations regarding samples of the State basic education standards and basic education programmes (2018) and Cabinet Regulations regarding the State standard of general secondary education and samples of General Secondary education programmes (2019). The primary education standard lists as one of the results to be achieved in the context of learning history which is: "the student thinks and acts responsibly, knowing the consequences of his actions and respecting life as a value. He has developed sustainable, beneficial social habits in communication and interaction with fellow human beings, has developed national, historical and civic awareness and understanding of social and economic processes." (Ministru Kabineta noteikumi Nr. 747, 2018), while the standard of secondary education mentions it as one of the complex results to be achieved in the context of history acquisition: "the student explains the events of the world, their causation and idealistic background in the past and in the present, expresses his attitude towards social, economic, political processes and engages responsibly in them, takes decisions related to career and future opportunities and has a positive impact on prosperity locally and globally, sees injustice and acts in such a way as to prevent it, 
treat it with dignity and understanding with society for diversity of purposes." (Ministru Kabineta noteikumi Nr. 416, 2019).

The relatively low results of students' in State exam of History highlight the need to review the selected pedagogical approaches and learning methods, which would contribute to a more in-depth understanding of the processes of history, their causation and the impact of historical processes on present day - key aspects of the history learning methodology are the collection and availability of historical information, the promotion of historical causation analysis, and the analysis of historical sources to promote critical thinking and collaborative skills (Quanchi \& So'o, 2003, p. 11-12). Learning history must not be confined to stating facts, history cannot be seen as an isolated chain of events, the process of learning history must promote the systematic thinking of students by offering a broad spectrum of information (Weiner, 1995), provide students with transparent and easily accessible information, e.g. through PowerPoint presentations, to explain complex concepts of historical events (Neumann, 2015). At the high school stage, it is possible and even necessary to apply modular technology to the pedagogical process using information technologies that promote student cognitive and cognitive skills: analyse, synthesize and critically evaluate available information, and communication skills (Vjazemskij \& Strelova, 2000). The use of information technologies in the learning of History and Culturology contributes to an active and meaningful learning process, helping students to critically assess past events, understand the consequences of past events today, thereby modulating a possible future development scenario. In addition, for choosing the methods of teaching History or Culturology, the types of interaction between the teacher and the student that are geared towards the objective of the learning process, it is important to promote the personal attitudes of the student towards a specific historical and social cultural events (Vagin, 1972).

The use of learning methods methods in learning process should also follow the trends of the 21 st century and audience a demand of the society. Therefore, more and more attention should be paid to interactive learning methods that would clearly facilitate student's learning and simplify the learning of the subject. History and Culturology, as subjects are very grateful for the use of interactive techniques. There are so many interesting websites where it is possible, for example, to walk virtuously around Ancient Egypt, Greece, visit the prehistoric Lasko cave, learn more about Latvia's occupation in the virtual museum, etc. We, teachers, must also provide knowledge where to seek the necessary information, encourage students to constantly and critically assess available information on the Internet. While understanding the need for the development of a learning approach in line with the dominance of modern technologies in society, as well as thinking about the availability of the learning content to be acquired by students to the acquisition of a History and Culturology at a secondary school stage and the experience of the author working as a History and Culturology teacher for 10 years, the author independently developed an interactive learning platform of Latvian and world history. www.pavelsjurs.lv

The interactive learning platform www.pavelsjurs.lv was developed in September 2014 on the basis of own-initiative and pedagogical experience, working as a teacher of History and Culturology. According to the information provided by Google Analytics (http://analytics.google.com), between September 2014 and January 2020, 38887 users visited the interactive learning platform www.pavelsjurs.lv, mainly using learning materials of subjects of History of Latvia and World, as well as Culturology for grades 10-12. The home page, which is intended not only for secondary pupils or students, but also for any lead, provide:

- Presentations by the author using more than 40 different sources of literature, providing a comprehensive view of the content of the subject "History of Latvia and the World". Presentations that allow students to download in PDF and PPS formats in a free approach are all topics for educational content (Essence and topicality of history; 
Prehistory; Ancient civilizations; Ancient Greece; Ancient Rome; Early Medieval Europe and the Baltics; The origins of Christianity and the formation of the Christian world; Islam and the Islamic world; The advanced Middle Ages; Medieval Livonia and Lithuania; Europe in the late Middle Ages; Renaissance and Reformation; Big geographic discoveries. American, Chinese, Indian, and Japanese civilizations; Europe and the world in the age of absolutism and enlightenment; The Baltics in the Age of Absolutism and Enlightenment; The Great French Revolution; The Baltics, Europe and the World in the Industrialization Era in the First Half of the 19th Century; The Baltics, Europe and the World 2nd half of the 19th century - early 20th century; First World War. Acquisition of Latvian independence; Europe and the world in the inter-war period; Latvia and the Baltic States in the 1920s and 1930s; Second World War; A split world; Communist regime in Latvia and the Baltics; Present day). To make it easier for users to navigate the topics, the structure of the website divide into sections by grades $10,11,12$, which contain topics relevant to each class.

- In addition to the free download of presentations on each topic, students have access to audio lectures created by the author on the website and presentations of cultural history in selected topics.

- A set of homework tasks is available for students under each topic, prepared by the history teacher, V.Klišāns, as well as free-access video resources from www.youtube.com and other different types of website that expand students' sight helps to better understand the subject to be learned.

- Thanks to material developed by teacher L.Zitāne, the website has access to the "Culturology" section, where students can download a variety of presentations dedicated to cultural-related topics: Cultural Theory Issues (Circles of Culture, Concept of Culture, Nature, Culture and Man, Material and Spiritual Culture, Culture of Signs and Symbols), Prehistory and Ancient Middle Eastern Cultures (Perceptions of the Mythical World, Prehistoric Culture, Mesopotamia, Egyptian, Hebrew Culture), Middle Eastern and Far Eastern Cultures (Indian Culture, Vedas and Hinduism, Buddhism, Chinese Culture, Philosophy, Chinese Intellectual Heritage and Achievements), Ancient Culture (Ancient and Ancient Roman Culture, Ancient and Ancient Roman Intellectual Heritage), Medieval Culture (Byzantine and Islamic Culture, Medieval Culture and Theo centrism), Renaissance Culture (Man and Society in Renaissance Culture, Importance and Ideas of Renaissance, Renaissance Art and Architecture), Culture of Absolute Enlightenment (Absolutism and Court Culture, 18th Century Ideas and Enlightenment, Intellectual Achievements of Absolutism and Enlightenment, Rococo, Realism and Classicism), 19th century culture (19th Century Man and Society, Key Ideas, Scientific and Technological Achievements 19th Century Art and Architecture), 20th Century Culture (20th century) Century Social Life, Postmodern Tendencies, Main Ideas, Youth Counterculture, Science Development, 20th Century Art and Architecture), Latvian Culture (Ancient and Traditional Latvian Culture, Medieval and Reformation Culture in Latvia, Latvian Culture from 17th Century to first 19th Century) Party, Fine Arts and Architecture at the Turn of the 20th Century in Latvia, Latvian Culture in the 20-30s of the 20th Century, Latvian Culture in the Soviet Times).

- Thematic planning of the subject for each class group and methodological suggestions for the development of reasoned essays.

- Useful open-access Internet resources for deeper study of History and awareness raising. 


\section{Approbation of an interactive learning platform in student assessment}

In order to evaluate effectively, systematically and objectively the created interactive learning platform for the subjects of History and Culturology, in autumn 2019, a survey was carried out in one of Latvia's general education institutions. The respondents were 10-12 grade students who use on daily bases the interactive home page www.pavelsjurs.lv. The aim of the survey was to clarify the assessment of students on the created learning tool and to identify learning growth indicators using the home page. The survey involved 86 respondents (grade 10-12 students).

In first part of the survey, students had the opportunity to assess the impact of information technologies on the learning process and on the use of information technologies in the educational process (Figure 1). From the answers given by the respondents, it can be concluded that:

- the majority of respondents (98\%) are convinced that the use of information technology can improve the learning process;

- the majority of respondents $(82 \%)$ are convinced that teachers targeted use information technology in the learning process;

- the majority of respondents (74\%) are convinced that the use of information technology in school curricula is appropriate and sufficient.

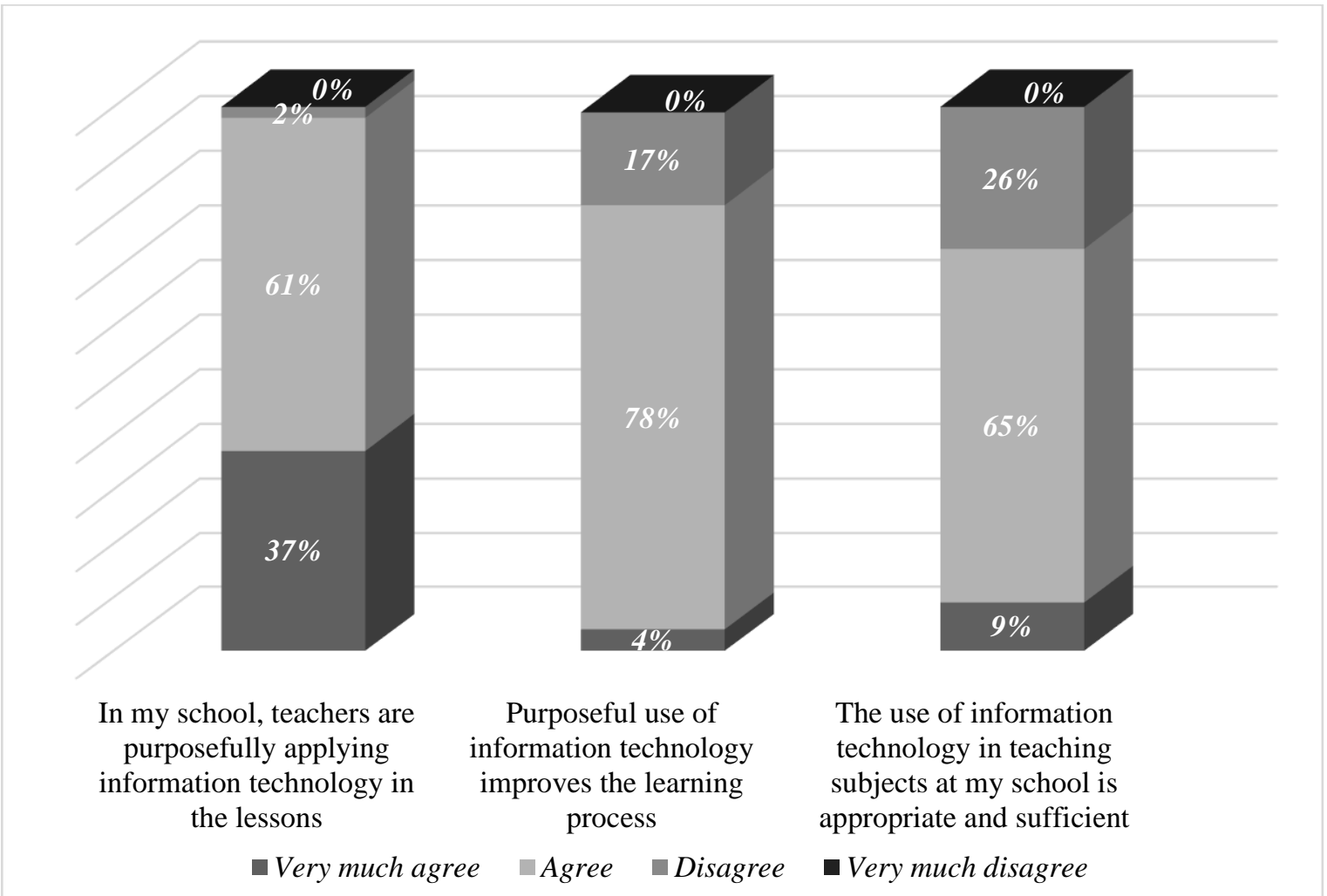

Figure 1 Students' self-assessment of the use of information technology in the learning process

In second part of the survey, students had an opportunity to evaluate the developed interactive learning platform (home page www.pavelsjurs.lv) in Latvian and World History, Culturology studies (Figure 2). From the answers, it can be concluded that:

- all respondents (100\%) admit that the developed website helps to better acquire study material in History and Culturology studies; 
- almost all respondents (98\%) admit that the developed home page helps to better understand historical and cultural processes;

- all respondents (100\%) admit to using the developed home page in preparation for tests in the History and Culturology studies;

- almost all respondents (98\%) admit that the developed website is necessary for History and Culturology studies.

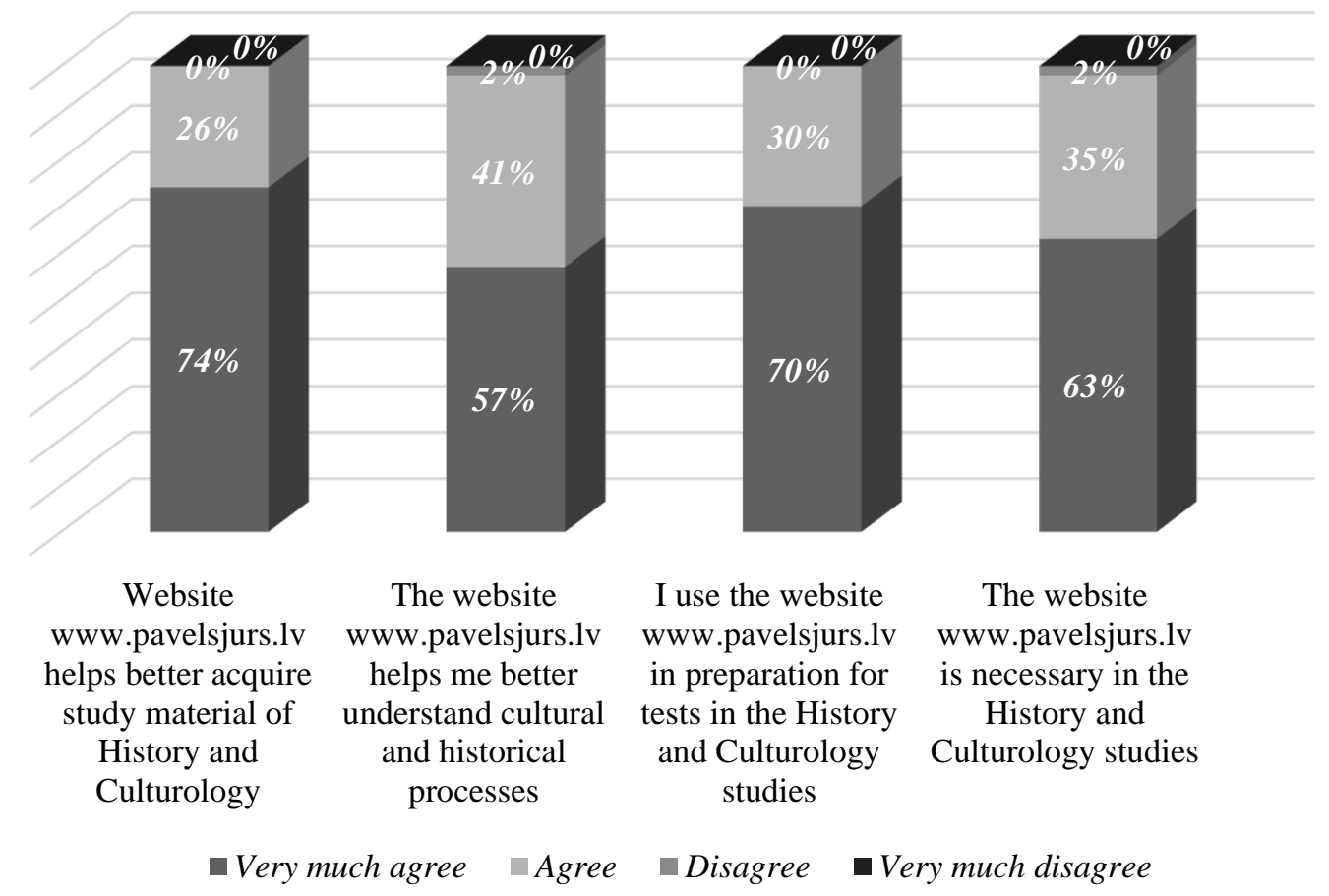

Figure 2 Students' self-assessment of the personal development through using of interactive learning platform (home page www.pavelsjurs.lv)

In the third part of the survey, respondents had the opportunity to mention the benefits of the website. The students noted that the website is: (I) thoughtful and interesting because it includes both video and audio recordings to help you better understand the subject; (II) easy to understand, easy to navigate and information are secure and reliable; (III) very useful in cases where the student is unable to attend the class, since absenteeism can have a significant impact on a student's learning outcomes; (IV) a very good resource for developing your understanding of historical and cultural historical events in Latvia and the world. On the other hand, respondents mentioned suggestions for improving the website: (I) to rethink the visual design of the website; (II) to develop the mobile phone version and application of the website; (III) to offer information and learning materials in English and Russian.

\section{Conclusions}

1. Purposeful and pedagogically based use of information technologies in the learning process stimulates students' interest in the subject being studied, promotes student's achievement and the diverse teaching and learning process. In this way, the digitalisation of curricula and teaching aids acquires topicality in the pedagogical process, facilitating access to education and promoting digital competence among students. 
2. In the age of information technology, promoting digital competence among students is becoming one of the most important elements of learning and pedagogical process. The concept of students' digital competence includes: (I) students' knowledge and skills, by carefully analysing and critically evaluating, obtaining and processing information; (II) safe and dignified virtual cooperation between students' using different forms of communication; (III) knowledge, skills and dignity of students' in the development, storage and distribution of digital content; (IV) students' knowledge, skills and responsibility for security and problem-solving aspects in the digital environment.

3. The versatile use of teaching methods should follow 21 st century trends, labor market demands and request of audience. As a result, digital competence issues and interactive teaching methods are increasingly being addressed in the pedagogical environment, which would clearly facilitate student learning and simplify the learning process of subjects.

4. The challenge of teaching the subjects of History and Culturology is not only to raise awareness of the causal relationships and interactions between historical and cultural processes, but also to foster students' systematic thinking, imagination and visual perception of historical and cultural events, providing students with transparent and easily accessible digital information in the form of presentations, videos and audio, thus allowing students to understand the characteristics of a particular era.

5. The empirical research carried out confirms the importance and effectiveness of the developed interactive learning platform (home page www.pavelsjurs.lv) in the learning process in the process of learning History and Culturology, promoting students' interest and understanding of historical and cultural processes. At the same time, interactive learning platform needs the visual and technical improvements.

\section{References}

European Commission. (2018). Council Recommendation on Key Competences for Lifelong Learning. Brussels. Retrieved from: https://eur-lex.europa.eu/legalcontent/EN/TXT/?uri=COM:2018:0024:FIN

European Commission. (2007). Key Competences for Lifelong Learning - A European Framework. Belgium. Retrieved from: https://www.britishcouncil.org/sites/default/files/youth-in-action-keycomp-en.pdf

European Commission. (2007). Europe's Digital Progress Report 2017. Brussels. Retrieved from: https://ec.europa.eu/digital-single-market/en/news/europes-digital-progressreport-2017

Eurostat data. (2015). The Digital Economy and Society Index. Indicator on "digital skills". Retrieved from: https://digital-agenda-data.eu/datasets/desi/indicators

Fišers, R. (2005). Mācīsim bèrniem mācīties. Rīga: RaKa.

Kluzer, S., \& Rissola, G. (2015). Guidelines on the adoption of DigComp. Belgium: Telecentre Europe.

Latvijas Republikas Izglītîbas un zinātnes ministrija. (2015). Digitālā kompetence izglìtības procesā. Retrieved from: https://www.izm.gov.lv/images/sabiedriska_lidzdaliba/aktualitates/NEPLP_110515_ppt .pdf

Ministru Kabineta noteikumi Nr. 416. (2019). Noteikumi par valsts vispārējās vidējās izglītības standartu un vispārējās vidèjās izglītības programmu paraugiem. Rīga: Ministru Kabinets. Retrieved from: https://likumi.lv/ta/id/309597-noteikumi-par-valstsvisparejas-videjas-izglitibas-standartu-un-visparejas-videjas-izglitibas-programmuparaugiem 
Ministru Kabineta noteikumi Nr. 747. (2018). Noteikumi par valsts pamatizglītības standartu un pamatizglìtības programmu paraugiem. Rīga: Ministru Kabinets. Retrieved from: https://likumi.lv/ta/id/303768-noteikumi-par-valsts-pamatizglitibas-standartu-unpamatizglitibas-programmu-paraugiem

Neumann, D. (2015). Using PowerPoint to Represent Complex Historical Concepts. The Source Teaching History in Digital Age. 8-9. The California History-Social Science Project.

Nikulina, N. (2000). Metodika prepodavanija istorii v srednej shkole. Kaliningrad: Kaliningradskij gosudarstvennyj universitet.

Quanchi, M., \& So'o, A. (2003). Teaching history. Brisbane: The Council of Presidents of Pacific Island History Associations.

Soldatova, G., Nestik, T., Rasskazova, J., \& Zotova, J. (2013). Cifrovaja kompetentnost' podrostkov i roditelej. Moskva: Fakul'tet psihologii MGU imeni M.V. Lomonosova.

Vagin, A. (1972). Metodika obuchenija istorii v shkole. Moskva: Prosveshhenie.

Valsts Izglītības satura centrs. (2019). Valsts pārbaudes darbi 2018./2019. mācību gadā. Oficiāāa statistika un rezultātu raksturojums. Retrieved from: https://visc.gov.lv/vispizglitiba/eksameni/statistika/2019/

Vjazemskij, J., \& Strelova, O. (2000). Kak segodnja prepodavat' istoriju v shkole. Moskva: Prosveshhenie.

Vuorikari, R., Punie, Y., Carretero, S., \& Brande, L. (2016). The Digital Competence Framework for Citizens. Joint Research Center: Luxembourg Publication Office of the European Union.

Weiner, R. (1995). History: Teaching and Methods. Education Resources Information Center. Zelmenis, V. (2000). Pedagogijas pamati. Rīga: RaKa.

Žogla, I. (2001). Didaktikas teorētiskie pamati. Rīga: RaKa. 